\title{
GIS and Hedonic Pricing for Green Space in Housing Area
}

\author{
Norzailawati Mohd Noor, M.Zainora Asmawi, \\ Alias Abdullah \\ Department of Urban and Regional Planning, \\ International Islamic University Malaysia \\ norzailawati@iium.edu.my
}

\begin{abstract}
This paper explores a framework that combines Geographic information System (GIS) with Hedonic pricing method in improving the analysis and determining the value of green spaces with housing prices in Subang Jaya, Malaysia. The previous study found that proposed combination between GIS and Hedonic pricing method for the same purpose has not been fully explored particularly in Malaysia. Findings show the proposed combined method leads to improved understanding and representation of urban dynamics and regeneration process, furthermore will encourage a sustainable setting of the environmental amenities in improving the geospatial technologies respectively.
\end{abstract}

Keywords: GIS, Hedonic Pricing Method, green Spaces and urban regeneration

eISSN 2398-4295 @ 2018. The Authors. Published for AMER ABRA cE-Bs by e-International Publishing House, Ltd., UK. This is an open-access article under the CC BY-NC-ND license (http://creativecommons.org/licenses/bync-nd/4.0/). Peer-review under responsibility of AMER (Association of Malaysian Environment-Behaviour Researchers), ABRA (Association of Behavioural Researchers on Asians) and cE-Bs (Centre for EnvironmentBehaviour Studies), Faculty of Architecture, Planning \& Surveying, Universiti Teknologi MARA, Malaysia.

DOI: http://dx.doi.org/10.21834/ajbes.v3i12.125 


\subsection{Introduction}

In urban areas, green spaces consist of parks and open spaces not only provide a pleasant and natural environment but also the quality of life and undertake essential environmental functions. An importance of urban green spaces in contributing fundamentally the quality of urban life has been stated by many researchers (Chiesura, 2004 and Biao et al., 2012 and TCPD, 2013). Recently, the residential property market in Malaysia has experienced significant price expansion over the past fifteen years with prices at several states experienced at a higher rate.

The Malaysia Valuation and Properties Services Department (JPPH) reported that the Malaysian house price Index increased by $8.0 \%$ in Q12014 relative to Q12013 and prices index changes over 12 months shows that increased from 1.5\% (Q1-Q42009) to 11.6\% (Q1Q42013) (JPPH, 2014). At the same time, there is growing evidence showing that a factor of house prices was influenced by green spaces as well the amenities and its infrastructure (Anderson and Cordell, 1988; Tyrvainen, 1997; Morancho, 2003). Since the green space is a part of natural resources and environmental amenities, it is a big challenge to measure the value of on willingness to pay (WTP) because they are non-market goods. The value of green space has been the subject of a good deal of research using the hedonic method and GIS and stated preference method as surveyed in various scholars.

The hedonic pricing method was revealed preference method to quantify a value from non-market goods purchased with housing properties. Meanwhile, GIS can easily provide an overall profile of land uses and open space surrounding the environmental amenity of interest in terms of their spatial distributions. Therefore, the objective of this paper is to analyse the approach of integration GIS-HPM in determining values of green spaces in housing prices. This paper firstly conducts a survey on the property attributes of 200 units of semi-detached in Klang Valley which represent by Subang Jaya, then uses GIS-HPM to analyse the relationship between property values and parks.

\subsection{Literature Review}

\section{Theoretical on Green spaces value using hedonic Pricing Methods and GIS}

The study on this topic study began with Morales et al. (1976) concluded that residential properties with good tree cover could raise total sale price by as much as $6 \%-9 \%$, Anderson and Cordel, (1988) found that landscaping with trees was associated with $3.5 \%-4.5 \%$ increase sales prices. Meanwhile, Luttik, (2000) was studied on 3000 houses transaction 8 towns in Netherlands found that a pleasant view could bring a considerable increase in house price based on lakes (8\%-10\%) and open space (6\%-12\%). A few years later, Crompton (2005) suggested that a positive impact of $20 \%$ on property values abutting or fronting a passive park was a reasonable starting point guideline. Sanders and Polasky, (2009) estimated a spatial error model with monthly and school district dummy variables on 9992 homes sold in 2005 in two Minnesota (USA) counties.

According to result, a 10\% increased in tree canopy cover within 100 meters increases the average home price $\$ 1371$. Conway et al., (2010) considered instead a spatial lag model to examine 260 homes sold in 1999/2000 in Los Angeles, California (USA) as a result 
consider that 1 percent increase in green space 200-300 meters from single family properties raise their value by $0.07 \%$. The study conducted by Zhang et al., (2012) found that urban green had positive and statistically significant influences on neighbouring property values; on average was a $5 \%-20 \%$ premium. The most recent in this study can be referred to Veie and Panduro, (2013) mentioned that proximity to parks and size of the park is associated with higher prices, the effect of size is small with approximately $0.01 \%$ increase in the price with a one percent increase in size.

The nature of green spaces which are non-commodity goods, it very challenging measure the monetary on a willingness to pay (More et al., 1998) because they are non-market goods. Therefore, different methods have been employed to estimate the value of urban green spaces. Several methods such as travel cost, contingent valuation method including hedonic pricing models have been developed and were improved in recent decades (Kong and Nakagoshi, 2007). Hedonic pricing method (HPM) is regression analysis of house sale transaction prices as a dependent variable with an array of explanatory variables, range of GIS-HPM context is expensive which, the utilization of Geographic information system (GIS) technique and software in estimating the green spaces as a factor for house prices have a potential to provide a reliable sets of results.

In recent decades, the development of GIS has gradually made hedonic pricing model a powerful tool, but at present, it is still underutilized in urban and environmental economics (Brasington and Hite, 2005; Norzailawati and Rosni, 2013). The common dictum that location is the most important parameter for real estate valuation can only be fully taken into account by using the descriptive framework of a GIS. One of the most basic advantages of a GIS is to position properties on local map in term their geographic coordinates (Din et al., 2001, Saphores and Li, 2012), which these can then be used to measure the environmental characteristic of properties better, increasing the understanding of house pricing variations as compared to previous study (Wyatt 1996).

\subsection{Methodology}

\subsection{Material}

Data contained average house sale price for Subang Jaya area. We select semi-detached houses and cadastral map retrieved from Town and Country Planning Department (TCPD) allowed delineation of property boundaries and to spatially reference the sample properties. Data on the extent and location of business, housing and recreational areas (parks and reserves) were obtained from GIS layer from (TCPD). A gravity index of industrial and recreational areas within $400 \mathrm{~m}$ (which is considered as within walking distance) for each property was constructed, adopted from Powe et al., (1997) to capture combined influence of their size and proximity to property value.

Table 1: Hierarchy of Open Space in Study Area

\begin{tabular}{|c|c|c|c|c|}
\hline No & $\begin{array}{l}\text { Hierarchy of open } \\
\text { space }\end{array}$ & $\begin{array}{l}\text { Acreages } \\
\text { (ha)- } \\
\text { requirement }\end{array}$ & $\begin{array}{l}\text { Population } \\
\text { catchment }\end{array}$ & Levels \\
\hline
\end{tabular}




\begin{tabular}{ccccc}
\hline 1 & $\begin{array}{c}\text { Neighborhood } \\
\text { Park } \\
2\end{array}$ & 2.0 & $3000-12000$ & $\begin{array}{c}\text { Local community } \\
\text { Playground }\end{array}$ \\
3. & 0.6 & $1000-3000$ & $\begin{array}{c}3 \text { sub- } \\
\text { neighborhood } \\
\text { area }\end{array}$ \\
& Play lot & 0.2 & $300-1000$ & $\begin{array}{c}\text { neighborhood } \\
\text { area }\end{array}$ \\
\hline
\end{tabular}

\subsection{Methods}

The study area was conducted in Subang Jaya, which is a suburban city in the Klang Valley, Selangor Malaysia, it is located at 303'52"N 101035'37'E. It is located about $20 \mathrm{~km}$ from the Kuala Lumpur city Centre. It comprises the southern third district of Petaling, making it the 5th most populous city in Malaysia. The specific study area is located at USJ and Putra Heights with an area is approximate $17473 \mathrm{ha}$. This site was covered by a semi-detached family housing which is identified from 5 selected areas (figure 1). As we refer to the annual price index for semi-detached housing in the study area which shows a tremendously increase in 14 years from 85.6 (the year 1999) to 244.8 in the year 2013 which brings the approximate gap of 159.2 due to rapid development and increasing of urban settlement, industrialization, and commercialization in the study area.

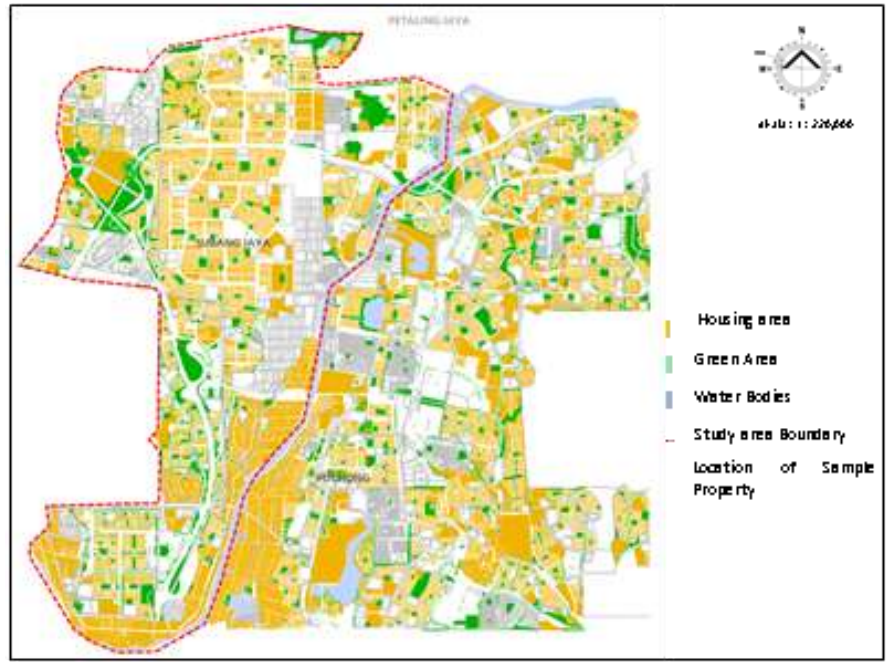

Figure 1: The Study Area and Geographic Distribution of Sample Properties

\section{Main Processing}

We firstly investigate the property characteristic of 50 samples of residential units with approximate 1100 ha of green area and apply hedonic price method to analyse the relationship between semi-detached value and its nearby park. In order to obtain a representative sample of each neighbourhood, the respondent includes real estate agents, 
household and planned property buyers. We create a survey form to record the neighbourhood characteristic of each sample property and its surrounding areas. The implicit prices of spillover benefits from the neighbourhood or environmental characteristic can be inferred based on the hedonic hypothesis (Rosen, 1974). Consequently, the traditional hedonic pricing model takes the following form:

$$
P=f(x 1, x 2, \ldots \ldots \ldots . . . x n)(1)
$$

Where $P$ is the market price of the housing and $x 1, x 2, \ldots \ldots \ldots . . . x n$ are the characteristic contained in the property. We choose average house price of per residential district as the housing price (P); proximity (PWRD), location (LST), size (SAD), hierarchy (HCAN), facilities (FSSU), maintenance (MROS) and cleanliness (CWOS). This study was used linear model (Kong and Nakagoshi, 2007) with four radiuses with a range of $100 \mathrm{~m}$ for each ring have been applied in this study, it significant to have 400 meters in compliment a standard walking distance.

\subsection{Results and Discussions}

The result in figure 2 shows that the average year of ownership of the semi-detached house in Subang Jaya mostly stayed for 6-10th years (36\%) and 11th-15th years $(22 \%)$ and its concurrent with the length of this area developed.
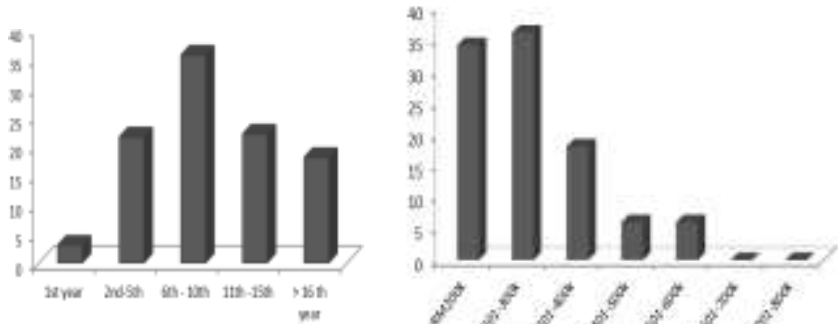

Figure 2: (a) Year of House Ownership; (b) Trânsacted price of House (when purchased) Meanwhile, a transacted price of house shows that the price when they purchased in a range of RM200-300k and $<$ RM200k. Using relative importance index to assess the element of open space which is might influences the proximate house prices shows that most of the respondent agreed to have cleanliness (CWOS) is very important in determining a value of each green spaces. Followed with a regularity of maintenance (MROS), seizes (SAD) and locations (LST).

The result shows that to have good prices, proximity is not a vital so as a facilities provided in each green spaces nearby their houses. This result a little bit different between previous studies might be due to local culture and attitudes (Table 2).

Based on the result of priority rank, the variables of sizes has been selected and tested using the GIS spatial analysis. Four rings with a range of 100 meters and estimate that the house price will increase between $3-12 \%(J P P H, 2014)$ are used to determine the value of 
green spaces. The neighbourhood park with above two hectares was used to be nodes and result found that in each range of $100 \mathrm{~m}$ to green space, the prices will be increased $3 \%$.

Table 2: Elements of Open Space Influences a House Prices in the Study Area

\begin{tabular}{lllc}
\hline No & $\begin{array}{l}\text { Elements of } \\
\text { Open Space }\end{array}$ & Elements of Open Space & $\begin{array}{c}\text { Priority } \\
\text { Rank }\end{array}$ \\
\hline 1 & PWRD & $\begin{array}{l}\text { The proximity is within reasonable } \\
\text { walking distance (400 meters) }\end{array}$ & 7 \\
2 & LST & $\begin{array}{l}\text { The location is strategic } \\
\text { The size is adequate }\end{array}$ & 4 \\
3 & SAD & $\begin{array}{l}\text { The hierarchy fulfils the catchment } \\
\text { area of users }\end{array}$ & 5 \\
4 & HCAN & $\begin{array}{l}\text { The facilities provided are sufficient } \\
\text { and suitable with the users }\end{array}$ & 6 \\
5 & FSSU & It has regular maintenance & 2 \\
6 & MROS & Cleanliness is well kept & 1 \\
7 & CWOS & &
\end{tabular}

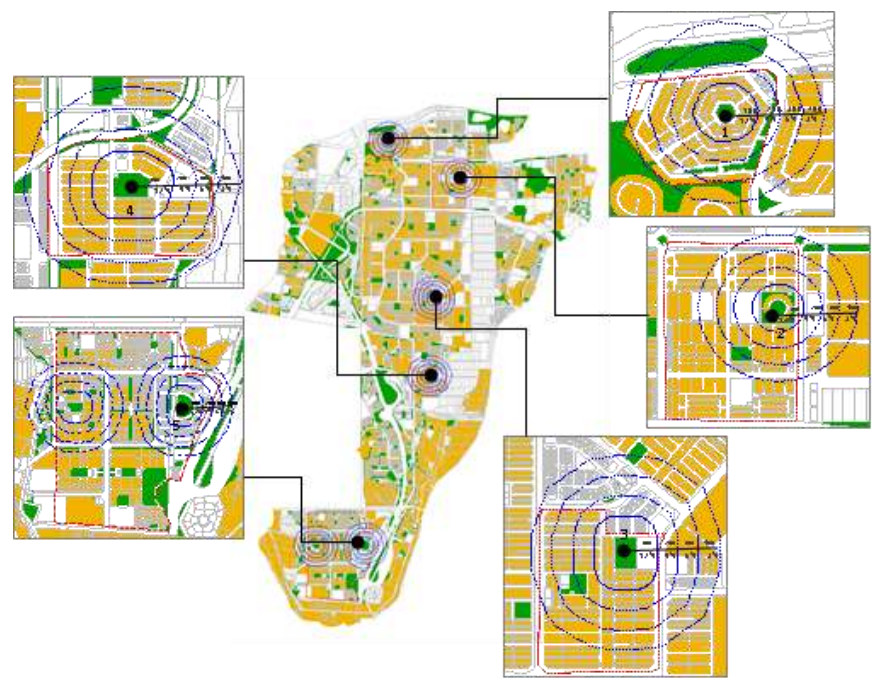

Figure 3: Spatial Distribution of Green Space Values within 400 Meter Radius

This result shows that based on green spaces size (neighbourhood parks), the possibilities of increasing in house prices is between 3-12\%. As expected, the results proved that the GIS-HPM performed well using this approach, and accordingly it was further improved. Results also confirmed the positive amenity impact of urban green spaces on house prices and highlighted the preferences of homeowners in Subang Jaya. Green space amenity variables that were statistically significant at the $5 \%$ level included the housing price (P); proximity (PWRD), location (LST), size (SAD), hierarchy (HCAN), facilities (FSSU), maintenance (MROS) and cleanliness (CWOS). By the large, the study presented evidence 
that green spaces statistically significant and positive impact on the prices of neighbouring properties and distribute of these benefits across regions.

These research findings could provide useful insights and hints for both real-estate developers and the government. GIS-HPM studies could help to refine the art and science of property valuation. It adds a new dimension to the study of related issues in Malaysia, including property purchase and sale, transfer, tax assessment, investment, and financing. Decision makers could apply the method to make an informed weighing of alternatives in land acquisition for residential development. The analysis could help judgment on marketability and potential profit margin. It could enlighten decision on whether to purchase a piece of expensive land situated in a densely urbanized area with limited room for green spaces, or a piece of cheaper rural land with similar green space rooms plus good external environment. The determination of sale prices of individual units could more accurately take into account people's preference and desire to have a view or access to green spaces and other environmental amenities.

\subsection{Conclusion}

Since urban green spaces have a positive impact on proximate property values, this represents a "capitalization" of park land into increased property values of proximate landowners. In this paper, we analysed the approach of integration GIS-HPM in determining values of green spaces in housing prices. It is a useful aid or guide to understanding the amenity value of urban green space. The future outlook for this study could aim at expanding studies in different categories of housing with varied variables of factors that influence a house price in Malaysia. Since last five years back, the housing prices in Malaysia are rigorously increased, therefore, to advocate quality of life through urban greening, the GISHPM could yield research finding that lend support the people in attributing an environmental value in a home purchase decision.

\section{Acknowledgement}

This research was supported by the Institut Penilaian Negara (INSPEN) for NAPREC research grant. The authors greatly acknowledge the Town Malaysian and Urban Planning Department, Malaysian Remote Sensing Agency and local authorities for providing invaluable respective data used in this study. Authors sincerely thank all referees for their suggestions to improve the manuscript.

\section{References}

Anderson, L.M., Cordell, H.K., (1988). Influence of trees on residential property values in Athens, Georgia (U.S.A.): a survey based on actual sales prices. Landscape. Urban Planning. 15, 153-164.

Brasington, D.M., Hite, D., (2005). Demand for environmental quality: a spatial hedonic analysis. Regional Sci. Urban Econ. 35, 57-82. 
Biao, Z., Gaodie, X., Bin, X. \& Canqiang, Z. (2012). The Effects of Public Green Spaces on Residential Property Value in Beijing. Journal of Resources \& Ecology 3(3): page 243 - 252.

Chiesura, A (2004). The role of urban Parks for the sustainable city landscape and urban planning, 129-138.

Conway, D., Li, C. Q., Wolch, J., Kahle, C., \& Jerrett, M. (2010). A spatial autocorrelation approaches for examining the effects of urban green space on residential property values. Journal of Real Estate Finance and Economics, 41, 150-169.

Crompton J.L. (2005). The Impact of Parks on property values: Empirical evidence from the past two decades in the United States. Managing Leisure, 10: 203-218.

Din, A., Hoesli, M., Bender, A., (2001). Environmental variables and real estate prices. In: the series papers with number 2001.04. Ecole des Hautes Etudes Commerciales, University de Geneve, Switzerland.

JPPH (2014). Laporan Indeks Harga Rumah Malaysia 2014. Jabatan Penilaian dan Perkhidmatan Harta. http://napic.jpph.gov.my/portal/portal/eps/Online+Services/Publication/PublicationPortletWindow?uri=/Publication _ EN/HPIM ain.htm\&action=2. Retrieved on 23th June 2014.

Kong, F., Nakagoshi, N., (2005). Changes in urban green spaces and their driving forces: a case study of Jinan City, China. J. Int. Dev. Cooperative. 11 (2), 97-109.

Kong F, Yin H, and Nakagoshi, N (2007) Using GIS and Landscape metrics in the Hedonic price modelling of the amenity value of urban green spaces: A case study in Jinan City, China. Landscape and Urban Planning 79,0240252.

Luttik J (2000). The value of trees, water, and open space as reflected by house prices in Netherlands. Landscape and urban Planning, 48: 161-167.

Morancho, A.B., 2003.A hedonic valuation of urban green areas. Landsc. Urban Planning. 66, 35-41.

More, T.A., Stevens, T., Allen, P.G., (1988). Valuation of urban parks. Landsc. Urban Planning. 15, 139-152.

Morales, D. J., Boyce, B. N., \& Favretti, R. J. (1976). The contribution of trees to residential property value: Manchester, Connecticut. Valuation, 23(2), 26-43.

Norzailawati M.N and Rosni N (2013). Determination of spatial factors in measuring urban sprawl in Kuantan using Remote Sensing and GIS. Procedia- Social and Behavioural Sciences, vol 85, pp 502-512.

Powe, N.A., Garrod, G.D., Willis, K.G., (1995). Valuation of urban amenities using a hedonic price model. J. Property Res. 12, 137-147.

Sander, H., Polasky, S., \& Haight, R. G. (2010). The value of urban tree cover: A hedonic property price model in Ramsey and Dakota Counties, Minnesota, USA. Ecological Economics, 69(8), 1646-1656.

Saphores J.D and Li W (2012). Estimating the value of urban green areas: A Hedonic Pricing Analysis of the single family housing market in Los Angeles, CA. Journal of Landscape and urban Planning 104, pp 373-387.

TCPD (Town and Country Planning Department) (2013). Garis panduan Perancangan: Tanah Lapang dan Rekreasi. Draft Kesembilan, Julai 2013. Jabatan Perancangan Bandar Semenanjung Malaysia. Malaysia.

Tyrvainen L (1997). The amenity value of urban forest: An application of the hedonic pricing method. Landscape and Urban Planning, 37:211-222. 
Veie K.L and Panduro T.E (2013). An alternative to the standard spatial econometric approaches in hedonic price models.: IFRO working paper 2013/18. The university of Copenhagen, Department of Food and Resource economics,

Wyatt, $P$ (1996). The development of a property information system for valuation using a geographical information system (GIS). Journal of Property Resource, 13, 317-336.

Zhang B., Xie G., Xia B and Zhang C (2012). The effects of public green space on residential property value in Beijing. Journal of Resource and Ecology 2 (3) 243-252. DOI: 10.5814lj.ISSN.1674-764x.2012.03.007. 